\title{
The Stratton Commission: The Model for a Sea Change in National Marine Policy
}

William J. Merrell, Mary Hope Katsouros, Jacqueline Bienski

The H. John Heinz III Center for Science, Economics and the Environment • Washington, DC USA

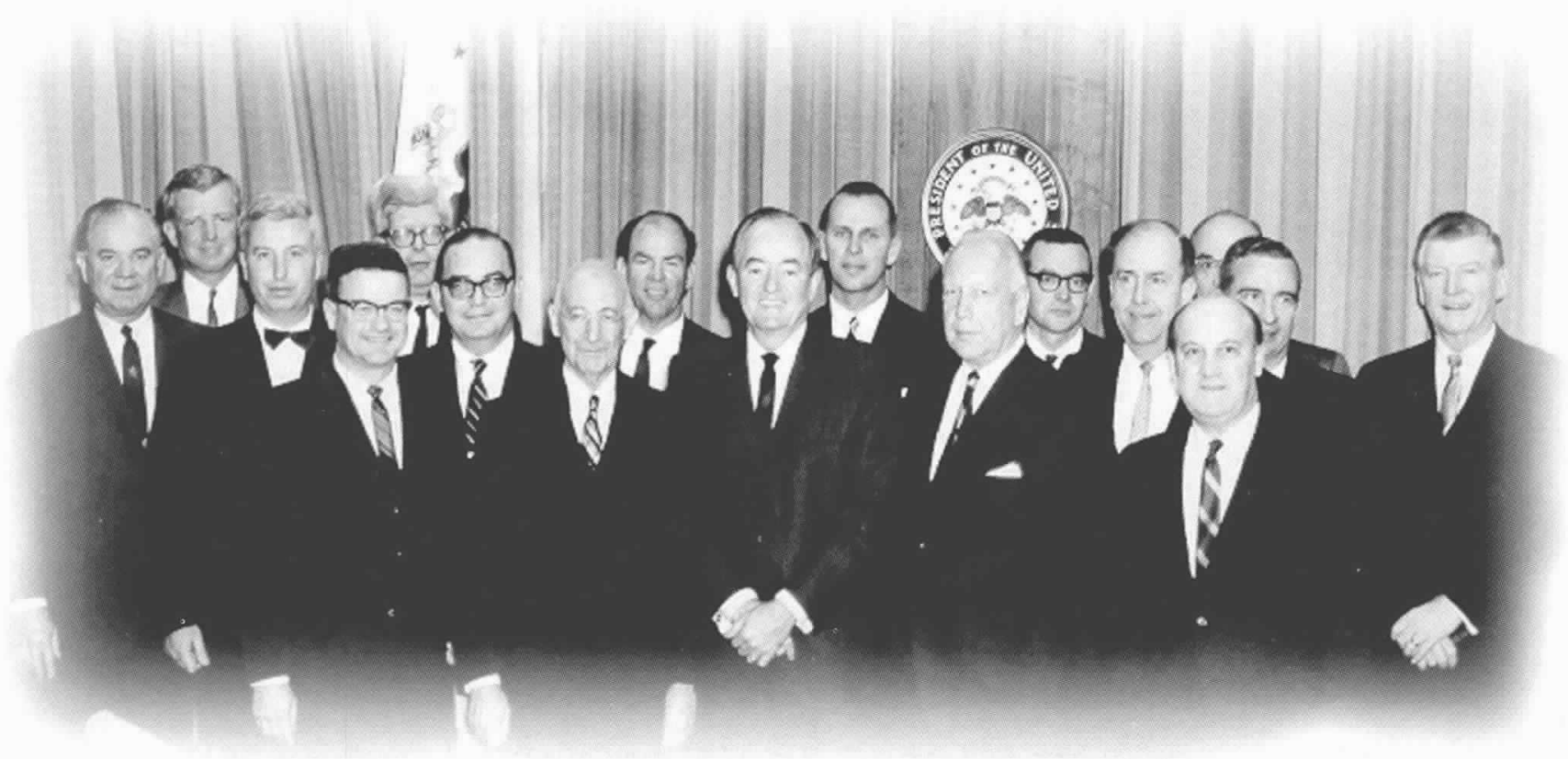

Figure 1. Members of the Stratton Commission left to right are: Leon Jaworski, Attorney, Fulbright, Crooker, Freeman, Bates, and Jaworski; Taylor Pryor, President, The Oceanic Foundation; John Knauss, Dean, Graduate School of Oceanography, University of Rhode Island; James Crutchfield, Professor of Economics, University of Washington; George Reedy, President, Struthers Research and Development Corporation; Robert White, Administrator, Environmental Science Services Administration, U.S. Department of Commerce; Jacob Blaustein, Director, Standard Oil Company (Indiana); John Perry, Jr., President, Perry Publications, Inc.; Hubert Humphrey, Vice President and Chair of the Marine Sciences Council; Charles Baird, Under Secretary of the Navy; Julius Stratton, Chairman, The Ford Foundation; David Adams, Commissioner of Fisheries, North Carolina Department of Conservation and Development; Richard Geyer, Head, Department of Oceanography, Texas A\&M University; Frank DiLuzio, Assistant Secretary, Water Pollution Control, U.S. Department of the Interior; George Sullivan, M.D., Consulting Scientist, General Electric Reentry Systems; Carl Auerbach, Professor of Law, University of Minnesota; Alton Lennon, U.S. Congressman, Advisor to the Commission.

In 1966, Congress enacted the Marine Resources and Engineering Development Act, which focused unprecedented attention on the nation's coasts and oceans. This major piece of legislation moved beyond issues of ocean science into the organization and improved coordination of federal ocean activities. It led the United States to propose the International Decade of Ocean Exploration (IDOE) in 1968 and to support the establishment of the World Weather Program. But the 1966 Act was best known for creating a blue ribbon presidential commission on marine science activities.

The Commission on Marine Science, Engineering and Resources, chaired by Julius A. Stratton, had a broad charter: to evaluate national needs and national capabilities and recommend appropriate governmental structure to meet those needs and maximize those capabilities. The Stratton Commission, as it came to be known, had an unprecedented and still unparalleled influence on the federal marine policies and priorities that have guided this nation for over 30 years. It is therefore appropriate in 
an issue dedicated to Dr. John A. Knauss, a member of the Stratton Commission, to review the origins, organization, and accomplishments of the Commission on Marine Science, Engineering and Resources.

\section{Science, Engineering and Resources}

Origins of the Commission on Marine

The 1966 Act that created the Commission on Marine Science, Engineering and Resources reflected a recognition that the nation was not making the most of its marine opportunities. It came at the end of a decade that began with Sputnik's sudden and

"We are just at the threshold
of our knowledge of
the oceans ... (This) knowledge
is more than a matter
of curiosity. Our very survival
may hinge upon it."
John F. Kennedy, 1961

shocking appearance orerhead, a decade during which science and technology, both in space and on the earth, rose to the top of the nation's priorities.

On October 4, 1957, the Soviet Union successfully launched Sputnik, the world's first artificial satellite, and just a month later Sputnik II carried the first living creature (Laika the dog) into space. These two events marked the beginning of a new age for American science and technology. The initial shock and fear gave way to a strong commitment to science as key element of national security, and this commitment produced significant increases in funding for U.S. science education and research.

This new interest in science and technology was not restricted to space science. On November 10, 1957, the National Academy of Sciences established a Committee on Oceanography (NASCO). The ten-member committee was chaired by Harrison Brown, a geochemist from California Institute of Technology.

Ocean issues were also generating broad international attention and consideration. In 1958, the United Nations convened the first international conference of plenipotentiaries "to examine the law of the sea, and to embody the results of its work in one or more international conventions. . " The 1958 conference produced four conventions that codified, to a great extent, customary law and brought international attention to the oceans.

On February 15, 1959, NASCO released its 12-volume report, Oceanograply 1960-1970. This report described the status of the nation's marine activities and set forth five general recommendations and twenty specific recommendations for science, technology, education and manpower, supporting services, logistics, resources, and international cooperation. The primary recommendation was to double the federal funding base for basic research, applied research, and surveys over the next ten years. During NASCO's deliberations, Senator Warren G. Magnuson of Washington State, chair of the Senate Commerce Committee, and Representative Herbert C. Bonner of coastal North Carolina, chair of the House Merchant Marine and Fisheries Committee, attended meetings at the invitation of Harrison Brown; NASCO members also briefed them regularly. Shortly after the release of the report, congressional interest mounted, and Senator Magnuson introduced Senate Resolution 136 to strengthen oceanography; it passed unanimously. A special subcommittee on oceanography was created in the House Merchant Marine and Fisheries Committee and held hearings on the NASCO report.

Also in 1959, President Eisenhower, with Executive Order 10807, established the Federal Council for Science and Technology (FCST). The Council's purpose was to enhance science and technology planning, to foster greater cooperation between federal 
agencies, and to provide the President with advice on federal programs that had impact on multiple agencies. On January 22, 1960, FCST created the Interagency Committee on Oceanography (ICO), partly in response to the NASCO report. In 1963, FCST released and submitted to Congress its first report on oceanography.

In 1961, President Kennedy sent a message to Congress proposing an expanded effort in ocean sciences and requesting additional funds. In part, he wrote: "We are just at the threshold of our knowledge of the oceans.... (This) knowledge is more than a matter of curiosity. Our very survival may hinge upon it." (Letter to the President of the Senate and the Speaker of the House of Representatives, May 29, 1961.) Congress responded favorably to the request for an increase in funding for oceanography, and a series of bills were introduced in both the House and Senate to consolidate and coordinate marine activities.

In September 1962, Congress passed H.R. 12601 to create a national policy in marine affairs, coordinated by the Office of Science and Technology. President Kennedy pocket-vetoed the bill when his advisors noted it was an encroachment on presidential authority and that OST was a staff agency and not appropriate to carry out line functions.

By 1965, Congress had recognized the need for more intensive and more coordinated government attention to the nation's marine interests, and two congressional ocean policy initiatives were put forth. Senator Magnuson introduced S. 944, calling for the establishment of a national oceanographic council at the cabinet level, and Representative Rogers introduced H.R. 9064, calling for the creation of a National Commission of Oceanography.

Also in 1965, the President's Science Advisory Committee (the successor to FCST) formed a Panel on Oceanography and charged it to draft goals for a national program, to assess current and planned activities, and to recommend measures to effect a program consonant with national needs. In June 1966, the panel issued its report, Effective Use of the Sea, which included among its recommendations a proposal for reorganization of the Executive Branch to deal more effectively with marine affairs. NASCO also published a new report, Oceanography 1966, with new recommendations for an oceanographic program and organizational structure.

All this activity and interest finally led to the passage of the 1966 Act and the formation of the Commission on Marine Science, Engineering and Resources. The House and Senate initiatives coalesced in May 1966 when the Senate and the House passed the Marine Resources and Engineering Development Act of 1966 as agreed to in

conference between the two Houses. It was signed into law by President Johnson as P.L. 89-454. Apparently, President Johnson would probably have vetoed the bill had it not been for his close personal relationship with Senator Magnuson. President Johnson and Senator Magnuson had been close colleagues in the Senate; in fact, Johnson had been Magnuson's best man. The story goes (Wenk, 1972) that the bill was sitting on the President's desk when Mrs. Magnuson approached him at a White House reception and asked whether he was going to sign or scuttle a bill that her husband had worked so hard for, to which he replied, "Honey, for you I'll sign it."

The 1966 Act created a cabinet-level council (the National Council of Marine Resource and Engineering Development), as recommended in the Magnuson initiative, but stipulated that it would be temporary. The

\section{BOX 2 \\ MEMBERS OF THE STRATTON COMMISSION}

CHAIR:

Julius A. Stratton

Chairman

The Ford Foundation

VICE-CHAIR:

Richard A. Geyer

Head

Department of Oceanography

Texas A\&M University

David A. Adams

Commissioner of Fisheries

North Carolina Department of

Conservation and Development

Carl A. Auerbach

Professor of Law

University of Minnesota

Charles F. Baird

Under Secretary of the Navy

Jacob Blaustein

Director

Standard Oil Company (Indiana)

James A. Crutchfield

Professor of Economics

University of Washington

Frank C. DiLuzio

Assistant Secretary -

Water Pollution Control

U.S. Department of the Interior
Leon Jaworski, Attorney

Fulbright, Crooker, Freeman,

Bates and Jaworski

John A. Knauss

Dean, Graduate School of

Oceanography

University of Rhode Island

John H. Perry, Jr, President

Perry Publications, Inc.

Taylor A. Pryor, President

The Oceanic Foundation

George E. Reedy, President

Struthers Research and

Development Corporation

George H. Sullivan, M.D.

Consulting Scientist

General Electric Reentry Systems

Robert M. White

Administrator

Environmental Science Services

Administration

U.S. Department of Commerce

CONGRESSIONAL ADVISORS: Sen. Norris Cotton (R-NH) Sen. Warren G. Magnuson (D-WA)

Rep. Alton A. Lennon (D-NC)

Rep. Charles A. Mosher (R-OH) 
Act also established a commission (the Commission on Marine Science, Engineering and Resources, soon to be known as the Stratton Commission) to evaluate national ocean needs and capabilities and to recommend government structures that would enable the nation to meet those needs and exploit those capabilities.

\section{The Commission}

The 1966 Act provided for a comprehensive, longrange, and coordinated national program in marine science, as well as for a National Council on Marine Resources and Engineering Development and a Commission on Marine Science, Engineering and Resources. Box 1 summarizes the 1966 Act.

The Commission on Marine Science, Engineering and Resources was charged "to make a comprehensive investigation and study of all aspects of marine science in order to recommend an overall plan for an adequate national oceanographic program that will meet the pre-

\section{BOX 3 STRATTON COMMISSION PANELS}

Panel on Basic Science

Robert M. White, Chair

John A. Knauss

Panel on Environmental Monitoring and on

Management and Development of the Coastal Zone John A. Knauss, Chair

Frank C. DiLuzio

Leon Jaworski

Robert M. White

Panel on Manpower, Education and Training

Julius A. Stratton, Chair

Richard A. Geyer

David A. Adams

Panel on Industry and Private Investments

Richard A. Geyer, Chair

Charles F. Baird

Taylor A. Pryor

George H. Sullivan

Panel on Marine Engineering and Technology

John H. Perry, Jr., Chair

Charles F. Baird

Taylor A. Pryor

George H. Sullivan

Panel on Marine Resources

James A. Crutchfield, Chair

David A. Adams

International Panel

Carl A. Auerbach, Chair

Jacob Blaustein

Leon Jaworski sent and future national needs," as specified in Section 5 .

The Commission's fifteen members were to be appointed by the President from federal and state government, industry, universities and laboratories and other institutions engaged in marine scientific or technological pursuits. The 1966 Act also provided for four members of Congress to act as advisors to the Commission. The four members of Congress invested considerable time and offered much leadership during the Commission's tenure.

By October 1966, the Council, as established under Section 3(a) of the Act, had completed the nomination process and submitted its list of names to the White House. The goal was a prestigious commission with the strongest possible members representing national interest and not just their own parochial marine interests, and some 900 nominations were reviewed and scrutinized. On January 9, 1967, President Johnson appointed the Commission, naming Julius A. Stratton chairman, the most critical appointment. A former president of the Massachusetts Institute of Technology and then chairman of the Ford Foundation, Julius Stratton had the gift of character and intellect. Box 2 lists the members of the Commission, and Figure 1 is a photo of the Commission.

In view of the broad charge to the Commission, the members organized themselves into working panels (Box 3), with the exception of the topic of government reorganization, which they approached as a committee of the whole. Each panel of two to four commissioners had an executive secretary. The seven panels became the vehicles for assessing the status of marine matters in their area. Each panel held hearings, received testimony, and contacted hundreds of individuals through correspondence or interviews. Samuel Lawrence, of the Office of Management and Budget, who served as the staff director for the Commission, supervised 35 staff members, 25 professionals and 10 support staff. Only about half the staff was paid from the Commission's $\$ 1.5$ million appropriation. The remainder were on loan from other federal agencies.

After gathering all the relevant information, the panels evaluated their issue topics and developed materials to be presented to the full commission. The Commission held 19 plenary meetings, lasting from two to four days. Several two-day meetings of the full Commission were devoted to "government organization best adapted to support" the national marine programs.

On January 9, 1969, two years after being appointed, the Stratton Commission released its report. Our Nation and the Sea was a comprehensive, forward-looking report that reviewed the status of most areas of American Ocean policy and offered 126 recommendations in 17 main categories. The cover price was $\$ 2.75$. The report emphasized three major issues: the oceans as the "New Frontier," the need to protect the coastal environment from overexploitation and pollution, and a detailed plan to reorganize Federal marine and coastal 
BOX 4

THE INFLUENCE OF THE STRATTON COMMISSION: OCEAN LEGISLATION, 1966-1976

Legislation/Public Law

Marine Resources and Engineering Development Act of 1966 P.L. 89-454

National Sea Grant College Program of 1966

P.L. $89-688$

National Environmental Policy Act of 1969

P.L. 91-190

1970 Reorganization Plans 3 and 4

Marine Mammal Protection Act of 1972

P.L. 92-522

Clean Water Act of 1972

P.L. 92-500

Coastal Zone Management Act of 1972

P.L. 92-583

Marine Protection, Research and Sanctuaries Act of 1972

P.L. 92-532

Endangered Species Act of 1973

P.L. 93-205

Magnuson Fishery and Conservation Management Act of 1976 P.L. $94-265$

\section{Description}

Comprehensive long-range and coordinated national program in marine sciences, established national council and commission on MRED.

Amends MRED. Authorizes, establishes the operation of Sea Grant Colleges - initiates education and research in various areas of oceanography and ocean resources.

Establishes national policy for the environment, establishes Council on Environmental Quality.

Environmental Protection Agency and National Oceanic and Atmospheric Administration created through Reorganization Plans 3 and 4.

Establishes a Marine Mammal Commission to ensure marine mammals maintain healthy populations.

Provides federal financial assistance and authorizes municipal sewage treatment plant construction facilities. Involves regulatory requirements that apply to industry and municipal dischargers. Sets pollution and water quality standards. Addresses oil and hazardous substance liability.

Authorizes federal grants to help states develop and implement comprehensive plans to help manage and conserve coastal waters.

Regulates international ocean dumping, provides for long-range research, establishes a National Marine Sanctuaries Program to identify, designate, and manage areas of nationally significant marine and Great Lakes water.

Conserves endangered species and threatened species of fish, wildlife and plants and the habitats where they live. Establishes prohibiting taking listed species to ensure the safety of the species.

Provides for conservation and management of fisheries. programs. In particular, the Commission proposed a new, independent civilian agency for administration of Federal civil marine and atmospheric programs.

\section{Major Outcomes of the Stratton Commission}

The Stratton Commission had a substantial impact on national marine sciences and policy. Within eighteen months its recommendation for a new civilian ocean and atmosphere agency was implemented with the creation of the National Oceanic and Atmospheric
Administration (NOAA). At first, however, the situation did not seem so bright-for more than a year, there was no movement towards the establishment of such an agency. In April 1970, Senator Fritz Hollings and Julius Stratton met with Attorney General Mitchell, a close friend of President Nixon, to enlist his support for a new ocean agency. The Attorney General would not agree to a new cabinet-level entity, but he did agree to support the creation of a new body within a department. This agreement was the substance of Reorganization Plan No. 4., which established NOAA 
within the Department of Commerce. (The Nixon Reorganization Plan differed from the Commission's in three fundamental ways: first, the plan placed NOAA in the Commerce Department, thus ignoring the recommendation that the agency be granted independent status; second, the Coast Guard was not included in the new agency; and third, the functions centering on the development of marine technology were also left out.) On January 28, 1971, President Nixon appointed Robert M. White, a Stratton Commission member, to head the new agency.

The Stratton Commission also recommended the establishment of a national coastal zone management program. The program would authorize grants-in-aid for state coastal zone authorities. The Coastal Zone Management Act (CZMA) was passed in 1972, creating a national coastal zone management program to be undertaken primarily by the coastal states with the cooperation and assistance of the federal government. This Act remains the basis of state policy and coordination in the coastal zone. In fact, all the ocean legislation listed in Box 4 can be traced to the Commission's report.

The Commission's call for a large increase in federal funding for marine sciences and technology was answered. After publication of the report, the federal marine science budget rose from \$463.4 million in FY69 to $\$ 514.3$ million in FY70 to $\$ 533.0$ million in FY71.

All in all, the Stratton Commission significantly changed the way this nation manages its oceans and the coasts; it also changed the organization of federal ocean science. The Commission's findings and recommendations have guided the nation for thirty-two years, and they are reflected in much of the legislation that governs our oceans and coasts, and in our priorities for federal ocean activities. In short, the Stratton Commission's vision has been and is still the blueprint for U.S. ocean science and ocean policy.

\section{FURTHER READING}

Abel, Robert B, 1981: The History of United States Ocean Policy. In: Making Ocean Policy: The Politics of Government Organization and Management. Francis Hoole, Robert Freidheim, and Timothy Hennessey, eds., Westview, Boulder, Colorado.

Commission on Marine Science, Engineering and Resources, 1969: Our Nation and the Sea: A Plan for National Action. U.S. Government Printing Office, Washington, D.C.

U.S. Congressional Research Service, 1976: The Legislative History of the Coastal Zone Management Act of 1972. U.S. Government Printing Office, Washington, D.C.

Wenk, Edward, Jr., 1972: The Politics of the Oceans. University of Washington Press, Seattle.

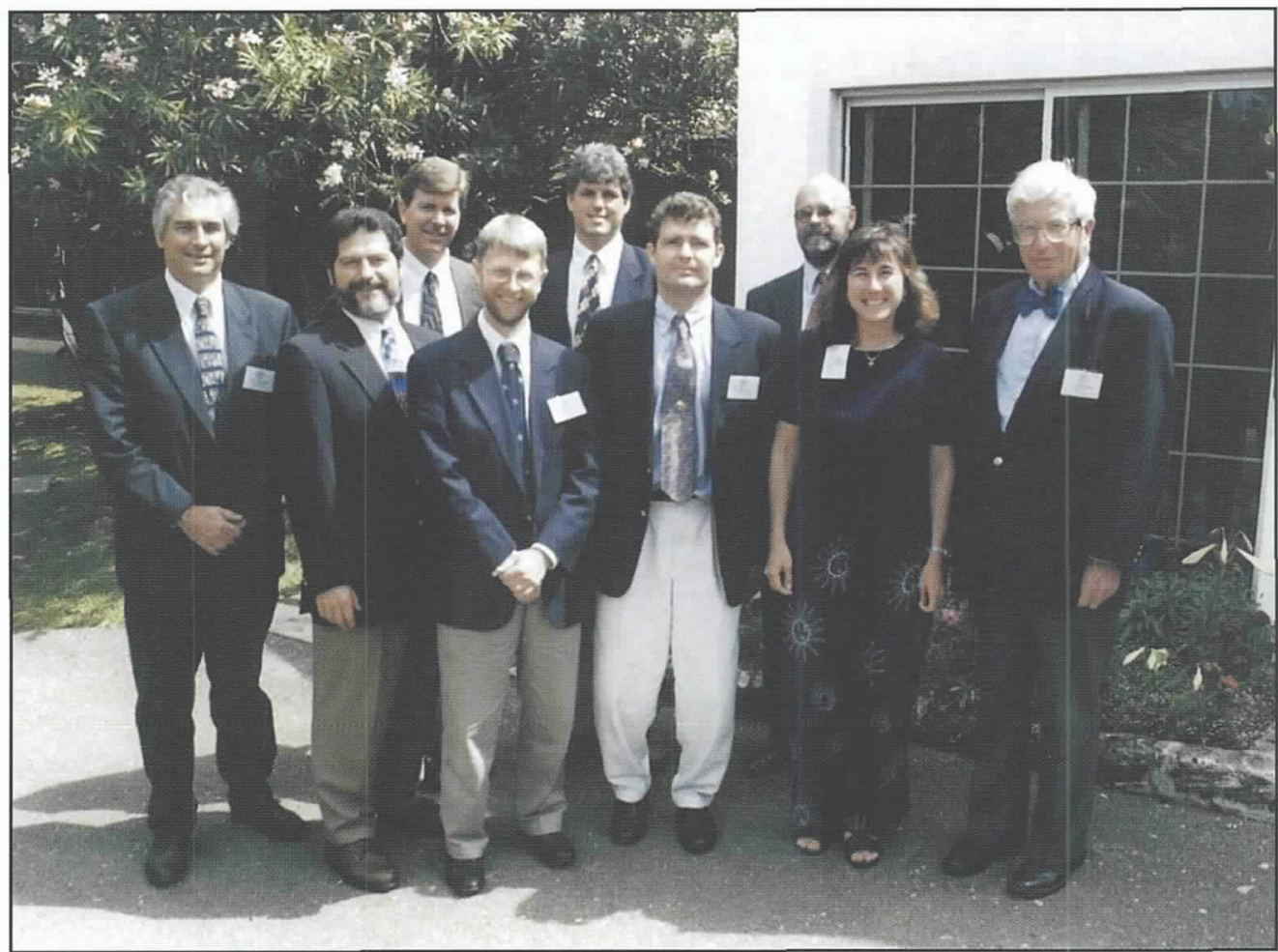

John Knauss with fellow symposium speakers at Bermuda Biological Station for Research symposium on ocean observations, April 29, 2000. Photo by Alison Shadbolt, Bermuda Biological Station for Research. 